\title{
Role of Nitric Oxide and Hydrogen Sulfide in the Vasodilator Effect of Ursolic Acid and Uvaol from Black Cherry Prunus serotina Fruits
}

\author{
Francisco J. Luna-Vázquez ${ }^{1}$, César Ibarra-Alvarado ${ }^{1, *}$, Alejandra Rojas-Molina ${ }^{1}$, \\ Antonio Romo-Mancillas ${ }^{1}$, Fabián H. López-Vallejo ${ }^{1}$, Mariana Solís-Gutiérrez ${ }^{1}$, \\ Juana I. Rojas-Molina ${ }^{1}$ and Fausto Rivero-Cruz ${ }^{2}$
}

Received: 2 December 2015 ; Accepted: 6 January 2016 ; Published: 12 January 2016

Academic Editor: Maurizio Battino

1 Laboratorio de Investigación Química y Farmacológica de Productos Naturales, Facultad de Química, Universidad Autónoma de Querétaro, Centro Universitario, Querétaro 76010, Mexico; fjlunavz@yahoo.com.mx (F.J.L.-V.); rojasa@uaq.mx (A.R.-M.); romtono@comunidad.unam.mx (A.R.-M.); fabianhlv@gmail.com (F.H.L.-V.); mariasolisgutierrez@gmail.com (M.S.-G.); jirojas@gmail.com (J.I.R.-M.)

2 Departamento de Farmacia, Facultad de Química, Universidad Nacional Autónoma de México, Ciudad Universitaria s/n, México D.F. 04510, Mexico; joserc@unam.mx

* Correspondence: cibarra@uaq.mx; Tel.: +52-442-1921200 (ext. 5527)

\begin{abstract}
The present research aimed to isolate the non-polar secondary metabolites that produce the vasodilator effects induced by the dichloromethane extract of Prunus serotina (P. serotina) fruits and to determine whether the NO/cGMP and the $\mathrm{H}_{2} \mathrm{~S} / \mathrm{K}_{\text {ATP }}$ channel pathways are involved in their mechanism of action. A bioactivity-directed fractionation of the dichloromethane extract of P. serotina fruits led to the isolation of ursolic acid and uvaol as the main non-polar vasodilator compounds. These compounds showed significant relaxant effect on rat aortic rings in an endothelium- and concentration-dependent manner, which was inhibited by NG-nitro-L-arginine methyl ester (L-NAME), DL-propargylglycine (PAG) and glibenclamide (Gli). Additionally, both triterpenes increased $\mathrm{NO}$ and $\mathrm{H}_{2} \mathrm{~S}$ production in aortic tissue. Molecular docking studies showed that ursolic acid and uvaol are able to bind to endothelial NOS and CSE with high affinity for residues that form the oligomeric interface of both enzymes. These results suggest that the vasodilator effect produced by ursolic acid and uvaol contained in P. serotina fruits, involves activation of the NO/cGMP and $\mathrm{H}_{2} \mathrm{~S} / \mathrm{K}_{\text {ATP }}$ channel pathways, possibly through direct activation of NOS and CSE.
\end{abstract}

Keywords: hydrogen sulfide; in silico study; nitric oxide; Prunus serotina; ursolic acid; uvaol; vasodilation

\section{Introduction}

Epidemiological studies over the last decade indicate that cardiovascular diseases are a major health problem worldwide, accounting for 30\% of deaths annually [1-3]. In the case of Mexico, these diseases are the leading cause of overall mortality [4-6]. Hypertension stands out among these ailments, with a growing incidence due to the increase of risk factors in modern society [7]. Currently, there are in the market over 200 drugs to treat hypertension, but less than a third of clinical cases are treated successfully because these drugs have low effectiveness and involve various side effects [8].

Numerous evidences suggest that alterations in the function of the vascular endothelium and a decrease in the availability of endothelial relaxing factors contribute to the pathogenesis and clinical expression of hypertension, among other cardiovascular diseases [9-11]. Thus, there is an ongoing search for new pharmacological strategies, whose targets of action activate the signaling pathways of the main vasodilator endothelial factors [12,13], including gasotransmitters, such as nitric oxide (NO) and hydrogen sulfide $\left(\mathrm{H}_{2} \mathrm{~S}\right)$ [14-23]. 
A documentary and ethno-medical study carried out by our research group indicated that among the plant species that are used in Mexico to treat cardiovascular disorders, one of the most well-known is Prunus serotina Ehrh (Rosaceae) (P. serotina) [24]. Therefore, our group carried out chemical and pharmacological studies of the leaves and fruits of this plant (Black cherry). A bio-directed chemical study of the methanol extract of the leaves led to the identification of hyperoside, prunin and ursolic acid as compounds with vascular smooth muscle relaxant activity [25]. We also determined that the aqueous and the dichloromethane extracts of black cherry fruits induce relaxation of vascular smooth muscle [26], which indicated that these fruits contain polar and non-polar metabolites with vasodilator effect, which may be useful for the prevention and/or treatment of cardiovascular diseases.

With respect to the characterization of polar metabolites, we found that the fruits of P. serotina have a high content of phenolic compounds such as chlorogenic acid, gallic acid, caffeic acid, catechin, epicatechin and quercetin and kaempferol glycosides, which are directly related to the high antioxidant capacity and significant vasodilator effect of the aqueous extract of the fruit [27].

In this context, the present research aimed to isolate the non-polar secondary metabolites that produce the vasodilator effects induced by the dichloromethane extract of $P$. serotina fruits and to determine whether the NO/cGMP and the $\mathrm{H}_{2} \mathrm{~S} / \mathrm{K}_{\text {ATP }}$ channel pathways are involved in their mechanism of action.

\section{Results}

\subsection{Bio-Directed Chemical Study of the Dichloromethane Extract Obtained from the Fruits of P. serotina}

The dichloromethane extract prepared from P. serotina fruits was fractionated by column chromatography (Figure 1), and the vasodilator activity was monitored through the isolated rat aorta assay. This assay showed that the relaxant activity on vascular smooth muscle was concentrated in the primary fraction PD-III.

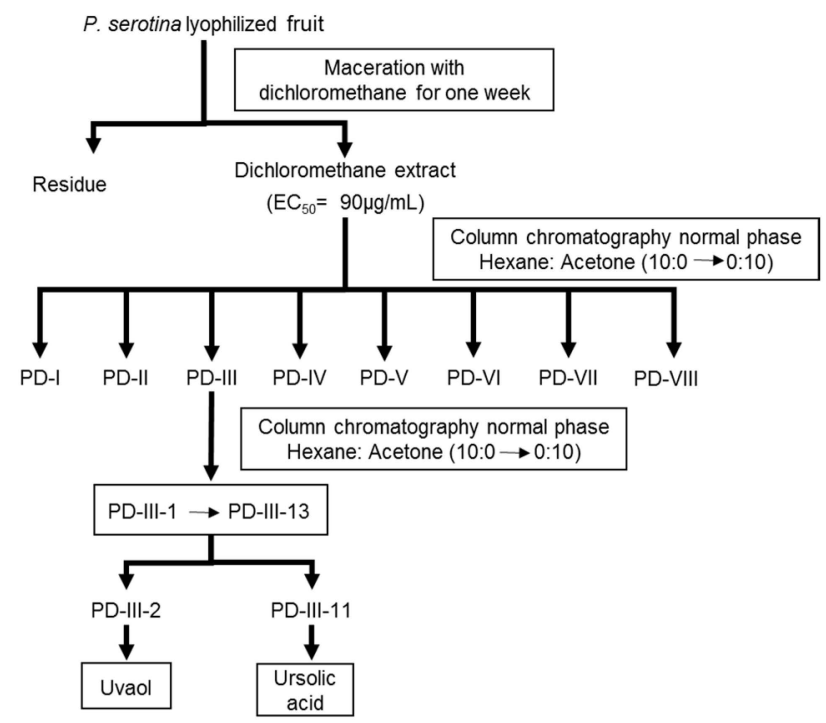

Figure 1. Diagram for extraction and bio-guided fractionation of the dichloromethane extract of Prunus serotina fruits.

Chromatographic analysis of fraction PD-III led to the isolation of a white compound with a melting point of $216-218{ }^{\circ} \mathrm{C}$ (fraction PD-III-2) and a white compound with a melting point of $259-260^{\circ} \mathrm{C}$ (fraction PD-III-11). These compounds were identified as uvaol and ursolic acid, respectively (Figure 2), by comparing their spectroscopic data $\left({ }^{1} \mathrm{H}-\mathrm{NMR}\right.$ and $\left.{ }^{13} \mathrm{C}-\mathrm{NMR}\right)$ with those previously described in the literature (Tables 1 and 2). 


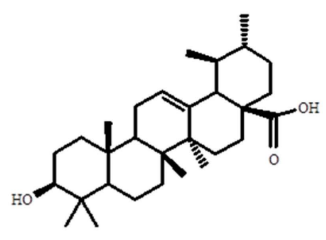

(A)

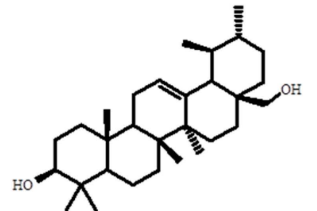

(B)

Figure 2. Chemical structures of ursolic acid (A) and uvaol (B).

Table 1. Spectroscopic constants of ursolic acid.

\begin{aligned} & \hline \multirow{3}{*}{${ }^{1} \mathrm{H}-\mathrm{NMR}(400 \mathrm{MHz}$, Acetone) $\delta(\mathrm{ppm})$}$\delta_{\mathrm{H}} 5.22$ (1H, m, H-12), 3.15 (1H, m, H-3), 2.25 (1H, d, H-18), 1.13 (3H, \\ &$\mathrm{s}, \mathrm{H}-23), 0.98(3 \mathrm{H}, \mathrm{s}, \mathrm{H}-27), 0.96(3 \mathrm{H}, \mathrm{s}, \mathrm{H}-26), 0.95(3 \mathrm{H}, \mathrm{s}, \mathrm{H}-24), 0.89 \\ &(3 \mathrm{H}, \mathrm{d}, \mathrm{H}-29), 0.84(3 \mathrm{H}, \mathrm{d}, \mathrm{H}-30), 0.78(3 \mathrm{H}, \mathrm{s}, \mathrm{H}-25) \\ &$\hline$\delta_{\mathrm{C}} 177.6(\mathrm{C}-28), 138.4(\mathrm{C}-13), 125.3(\mathrm{C}-12), 77.7(\mathrm{C}-3), 55.3(\mathrm{C}-5), 52.9 \\ &(\mathrm{C}-18), 47.5(\mathrm{C}-9), 47.3(\mathrm{C}-17), 41.9(\mathrm{C}-14), 39.5(\mathrm{C}-8), 38.9(\mathrm{C}-19), 38.9 \\ &(\mathrm{C}-4), 38.6(\mathrm{C}-1), 36.8(\mathrm{C}-22), 36.7(\mathrm{C}-10), 33.0(\mathrm{C}-7), 30.4(\mathrm{C}-21), 27.9 \\ &(\mathrm{C}-15), 27.8(\mathrm{C}-2), 24.1(\mathrm{C}-16), 23.1(\mathrm{C}-27), 23.0(\mathrm{C}-11), 20.5(\mathrm{C}-30), 18.2 \\ &(\mathrm{C}-6), 16.8(\mathrm{C}-26), 16.6(\mathrm{C}-24), 15.4(\mathrm{C}-29), 15.0(\mathrm{C}-25) \\ &$\hline\end{aligned}

Table 2. Spectroscopic constants of uvaol.

\begin{tabular}{ll}
\hline \multirow{2}{*}{${ }^{1} \mathrm{H}-\mathrm{NMR}\left(400 \mathrm{MHz}, \mathrm{DMSO}-d_{6}\right) \delta(\mathrm{ppm})$} & $\delta_{\mathrm{H}} 5.13(1 \mathrm{H}, \mathrm{t}, \mathrm{H}-12), 3.80(1 \mathrm{H}, \mathrm{d}, \mathrm{H}-20 \mathrm{a}), 3.38(1 \mathrm{H}, \mathrm{d}, \mathrm{H}-28 \mathrm{~b}), 3.20(1 \mathrm{H}$, \\
& $\mathrm{d}, \mathrm{H}-3), 1.05\left(3 \mathrm{H}, \mathrm{s}, \mathrm{CH}_{3}\right), 0.98\left(3 \mathrm{H}, \mathrm{s}, \mathrm{CH}_{3}\right), 0.97\left(3 \mathrm{H}, \mathrm{s}, \mathrm{CH}_{3}\right), 0.96(3 \mathrm{H}$, \\
& $\left.\mathrm{s}, \mathrm{CH}_{3}\right), 0.93\left(3 \mathrm{H}, \mathrm{d}, \mathrm{CH}_{3}\right), 0.83\left(3 \mathrm{H}, \mathrm{d}, \mathrm{CH}_{3}\right), 0.80\left(3 \mathrm{H}, \mathrm{s}, \mathrm{CH}_{3}\right)$. \\
\hline${ }^{13} \mathrm{C}-\mathrm{NMR}\left(100 \mathrm{MHz}, \mathrm{DMSO}-d_{6}\right) \delta(\mathrm{ppm})$ & $\begin{array}{l}\delta_{\mathrm{C}} 177.8(\mathrm{C}-28), 138.7(\mathrm{C}-13), 125.1(\mathrm{C}-12), 77.1(\mathrm{C}-3), 58.7(\mathrm{C}-18), 52.3 \\
(\mathrm{C}-5), 41.5(\mathrm{C}-14) .17 .9(\mathrm{C}-29), 15.9(\mathrm{C}-23) .\end{array}$ \\
\hline
\end{tabular}

\subsection{Elucidation of the Mechanism of Action of Ursolic Acid and Uvaol}

Ursolic acid $\left(\mathrm{EC}_{50}=21.5 \pm 3.5 \mu \mathrm{g} / \mathrm{mL} ; \mathrm{E}_{\max }=97.7 \% \pm 3.9 \%\right)$ and uvaol $\left(\mathrm{EC}_{50}=19.3 \pm 2.5 \mu \mathrm{g} / \mathrm{mL}\right.$; $\mathrm{E}_{\max }=93.4 \% \pm 5.1 \%$ ) caused a significant concentration-dependent relaxation of the aorta. ACh $\left(\mathrm{EC}_{50}=8.7 \pm 0.8 \mu \mathrm{g} / \mathrm{mL} ; \mathrm{E}_{\max }=69.5 \% \pm 5.7 \%\right)$, used as positive control, was more potent than ursolic acid and uvaol, but showed lower efficacy than both triterpenes.

Ursolic acid and uvaol relaxed the rat aorta by a mechanism that depends on the presence of the vascular endothelium, since endothelium removal reduced almost completely the vasodilator effect of these compounds (Figure 3).

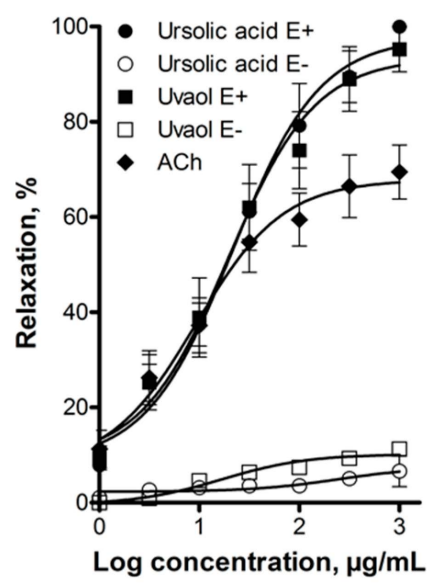

Figure 3. Concentration-response curves of the vasodilator effect of ursolic acid and uvaol in the presence $(\mathrm{E}+)$ and absence $(\mathrm{E}-)$ of endothelium. Acetylcholine (ACh) was used as positive control. Analysis by repeated-measures two-way ANOVA was made between the curves of each triterpene in the presence and absence of endothelium $(p<0.001)$. 
The vasorelaxant effect of these triterpenes was significantly reduced by inhibiting eNOS with NG-nitro-L-arginine methyl ester (L-NAME; $100 \mu \mathrm{M}$ ) or CSE with DL-propargylglycine (PAG; $10 \mathrm{mM}$ ), which indicated that the NO/cGMP and the $\mathrm{H}_{2} \mathrm{~S} / \mathrm{K}_{\text {ATP }}$ channel pathways are involved in this effect (Figure 4).
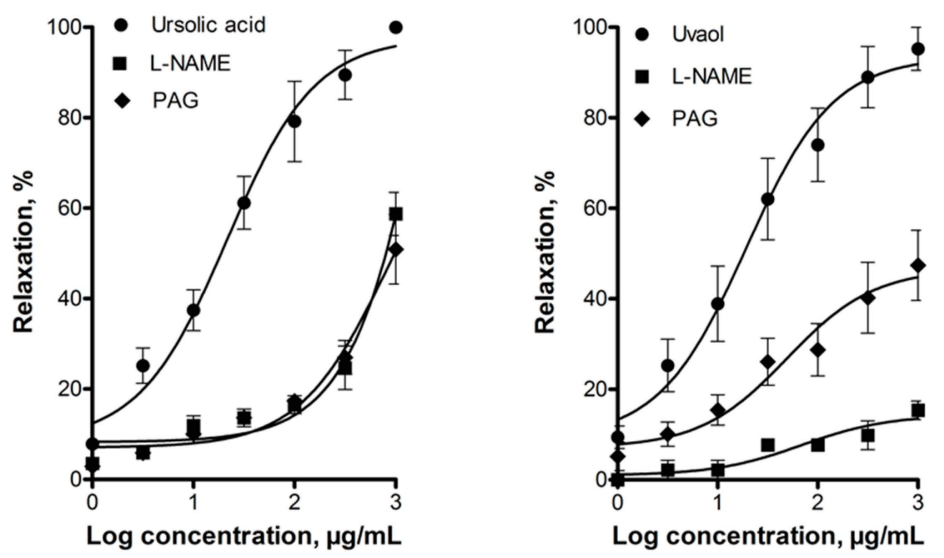

Figure 4. Vasodilatory effect of ursolic acid and uvaol in the absence (control) and presence of inhibitors of enzymes that produce gasotransmitters: NG-nitro-L-arginine methyl ester (L-NAME; $100 \mu \mathrm{M})$ and DL-propargylglycine (PAG; $10 \mathrm{mM}$ ). Analysis by repeated-measures two-way ANOVA was made between the curves of each triterpene in the presence of L-NAME or PAG $(p<0.001)$.

In order to evaluate the interaction between the NO/cGMP and the $\mathrm{H}_{2} \mathrm{~S} / \mathrm{K}_{\mathrm{ATP}}$ pathways in the vasorelaxant mechanism of action of ursolic acid and uvaol, submaximal concentrations of L-NAME $(1 \mu \mathrm{M})$ and PAG $(1 \mathrm{mM})$ and a mix of both inhibitors were evaluated. The simultaneous inhibition of both enzymes, eNOS and CSE, with submaximal concentrations of their respective inhibitors inhibited almost completely the vasorelaxant effect of the two triterpenes tested (Figure 5).
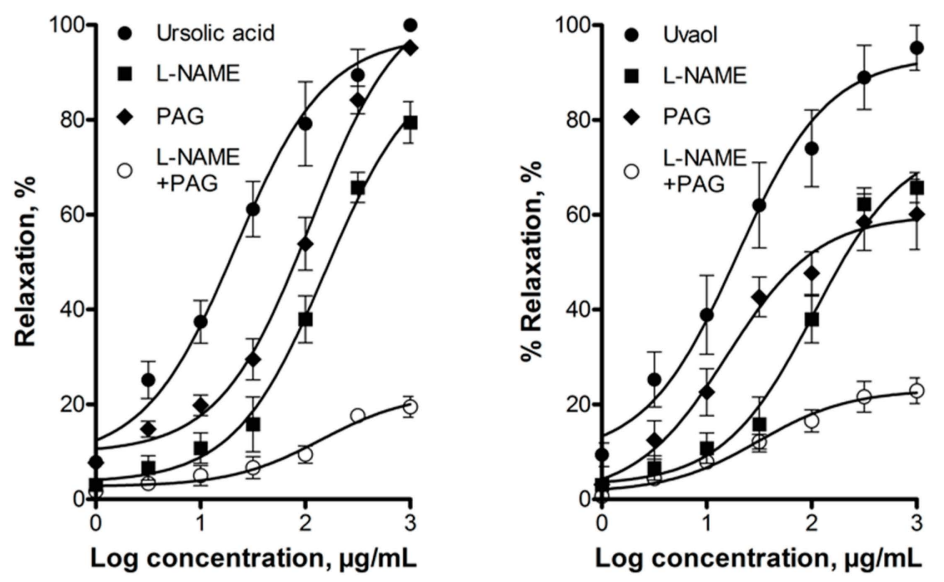

Figure 5. Vasodilatory effect of ursolic acid and uvaol in the absence (control) and presence of inhibitors of enzymes that produce gasotransmitters: L-NAME $(1 \mu \mathrm{M})$, PAG $(1 \mathrm{mM})$, and L-NAME $(1 \mu \mathrm{M})+$ PAG $(1 \mathrm{mM})$. Analysis by repeated-measures two-way ANOVA was made between the curves of each triterpene in the presence of L-NAME, PAG or L-NAME + PAG $(p<0.001)$.

To assess whether activation of ATP-sensitive $\mathrm{K}^{+}$channels was involved in the vasodilatory effect of these triterpenes, the effect of glibenclamide (a specific blocker of the $\mathrm{K}_{\mathrm{ATP}}$ channels) was evaluated. This blocker significantly shifted to the right the concentration-response curves of the vasodilator effect of ursolic acid and uvaol (Figure 6), indicating that these channels are involved in this effect. 

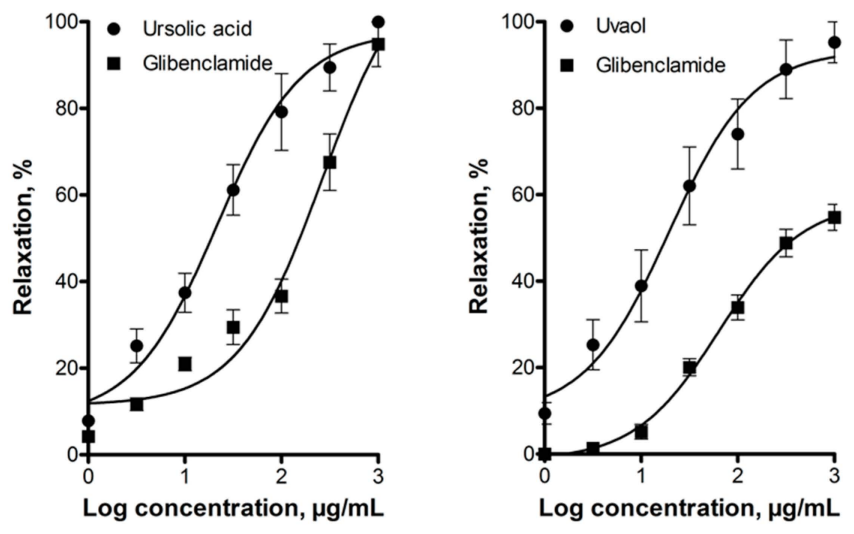

Figure 6. Vasodilatory effect of ursolic acid and uvaol in the absence (control) and presence of the potassium channel inhibitor glibenclamide $(1 \mu \mathrm{M})$. Analysis by repeated-measures two-way ANOVA was made between the curves of each triterpene in the presence of glibenclamide $(p<0.001)$.

To confirm participation of both $\mathrm{NO} / \mathrm{cGMP}$ and $\mathrm{H}_{2} \mathrm{~S} / \mathrm{K}_{\text {ATP }}$ channel pathways in the vasorelaxant effect of ursolic acid and uvaol, $\mathrm{NO}$ and $\mathrm{H}_{2} \mathrm{~S}$ levels were quantified in the aortic tissues. As expected, the nitrite concentration increased, when aortic tissue was incubated with ursolic acid $\left(\left[\mathrm{NO}_{2}{ }^{-}\right]=7.95 \pm 0.22 \mu \mathrm{M}\right)$ and uvaol $\left(\left[\mathrm{NO}_{2}{ }^{-}\right]=7.55 \pm 0.17 \mu \mathrm{M}\right)$; both triterpenes induced a higher nitrite concentration than that of $\mathrm{ACh}\left(\left[\mathrm{NO}_{2}{ }^{-}\right]=5.5 \pm 0.47 \mu \mathrm{M}\right)$. Similarly, quantification of $\mathrm{H}_{2} \mathrm{~S}$ showed that stimulation of aortic tissue with ursolic acid $\left(\left[\mathrm{H}_{2} \mathrm{~S}\right]=234 \pm 12.7 \mu \mathrm{M}\right)$ and uvaol $\left(\left[\mathrm{H}_{2} \mathrm{~S}\right]=253 \pm 6.8 \mu \mathrm{M}\right)$ increased four times the $\mathrm{H}_{2} \mathrm{~S}$ concentration with respect to the control. In the presence of $\mathrm{ACh}, \mathrm{H}_{2} \mathrm{~S}$ levels were only three times higher than those of the control (Figure 7).
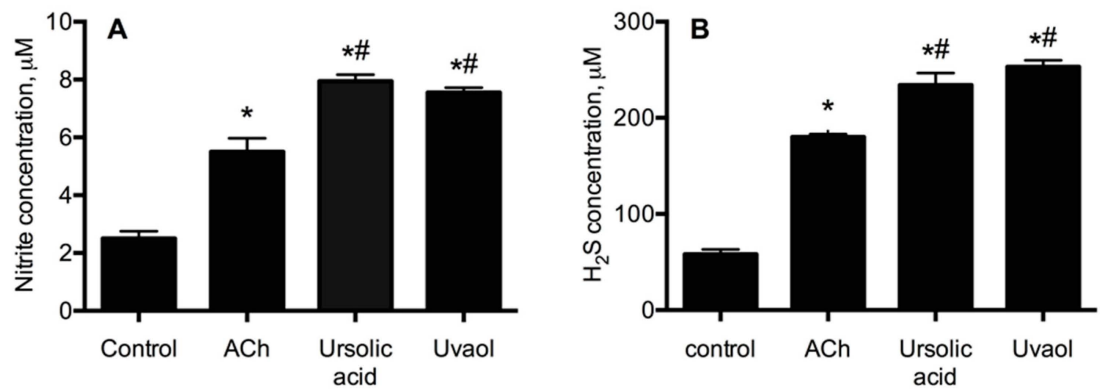

Figure 7. Total nitrite (A) and hydrogen sulfide (B) concentration induced by stimulation of aortic tissue with ursolic acid and uvaol. Statistical analysis was made using a one-way ANOVA, followed by a Tukey's test ${ }^{*} p<0.0001$ vs. control; \# $p<0.05$ vs. ACh).

Docking studies showed that ursolic acid and uvaol could bind to residues forming the oligomeric interfaces of eNOS and CSE, corresponding to the highest affinity binding sites of both enzymes. Additionally, both compounds displayed low affinity for the catalytic sites of the enzymes; however, they bind to a site close to the catalytic center, which could have an effect on the synthesis of NO and $\mathrm{H}_{2} \mathrm{~S}$ (Figure 8).

In eNOS, the $\mathrm{C} 1$ and $\mathrm{C} 2$ pockets where the triterpenes bind are away from the catalytic site and constitute the substrate access channel. These compounds are mostly stabilized by short contacts with residues of $\mathrm{C} 1$ and $\mathrm{C} 2$ sites and by hydrogen bonds with Asp480 and His373, as well as an electrostatic interaction with Arg367 (Figure 9).

As mentioned above, ursolic acid and uvaol showed preference for a binding site in CSE that shares residues from different chains, namely A and $B$. The proposed new binding site for the studied compounds is located ca. $12 \AA$ from the cofactor pyridoxal-5'-phosphate (PLP) binding site. As well 
as in eNOS, the binding of the triterpenes to CSE could be stabilized by hydrogen bonds with polar residues, namely His99 for ursolic acid and Leu100 and Arg235 for uvaol in CSE, as well as by short contacts with other amino acids (Figure 10).

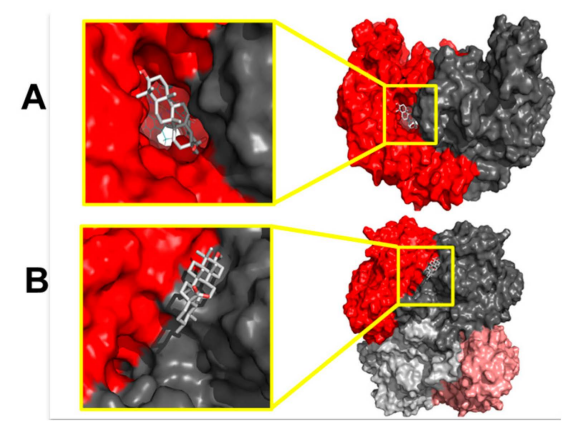

Figure 8. Molecular surface showing the oligomeric interfaces (color-code by chain) and the favored binding sites of triterpenes (Ursolic acid): (A) eNOS and (B) CSE. The homodimer interface is located along the region where the two monomers, labeled in different colors, connect.

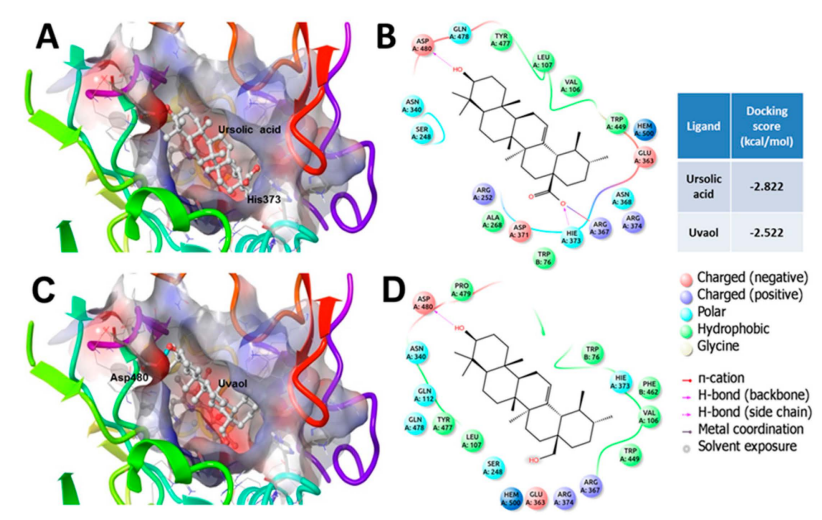

Figure 9. Binding mode of ursolic acid and uvaol into the eNOS binding site: (A) short interactions (4.5 $\AA$ ) of ursolic acid into the $\mathrm{C} 1$ and C2 pockets; (B) 2D ligand interaction diagram of ursolic acid; (C) Short interactions (4.5 $\AA$ ) of uvaol into the C1 and C2 pockets; and (D) 2D ligand interaction diagram of uvaol.

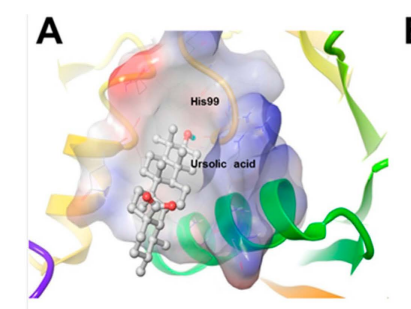

$\mathbf{B}$
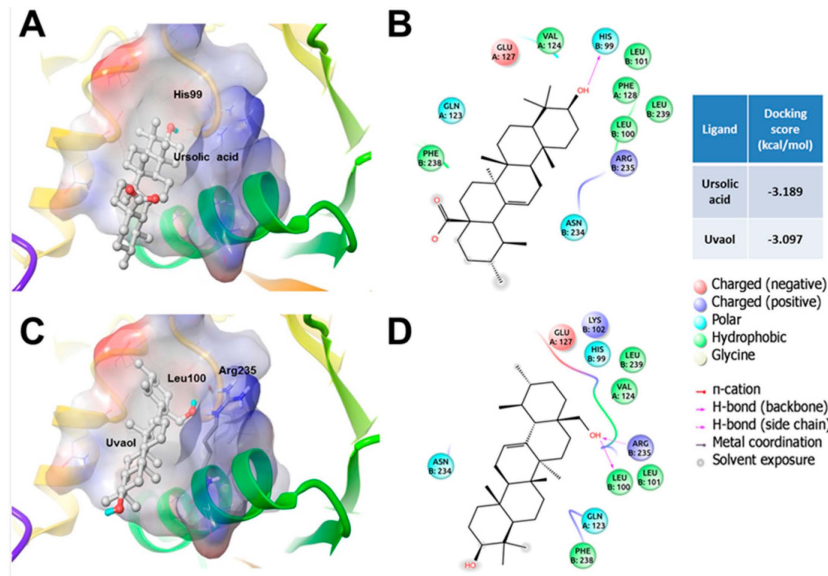

Hydrophob
Glycine

J

$\rightarrow$ n-cation
H-bond (backbone)

Metal coordination
Solvent exposure

Figure 10. Binding mode of ursolic acid and uvaol into the CSE shared binding site: (A) short interactions (4.5 $\AA$ ) of ursolic acid into the binding site; (B) 2D ligand interaction diagram of ursolic acid; (C) Short interactions (4.5 ̊) of uvaol into the binding site; and (D) 2D ligand interaction diagram of uvaol. 


\section{Discussion}

In this work, we determined for the first time that the triterpenes ursolic acid and uvaol are the main non-polar vasodilator compounds in P. serotina fruits.

Ursolic acid and uvaol are ursane-type pentacyclic triterpenes widely distributed in different plant parts of medicinal and food species $[28,29]$. These compounds have been identified in several species of the genus Prunus [30-34], and particularly our working group isolated ursolic acid from the leaves of P. serotina [25]. According to the total weight obtained, the percentages of ursolic acid and uvaol are approximately $0.04 \%$ and $0.02 \%$, respectively. Ursolic acid is recognized as a valuable medicinal natural product, which possesses several pharmacological activities, such as anticancer, antitumor, antiwrinkle [35,36]; antidiabetic [37]; anti inflammation [38], and anti-atherosclerotic [39], among others. On the other hand, uvaol, an important component of olive oil, has antiproliferative and antiatherogenic properties [40,41].

In previous studies, our research team and other groups reported that ursolic acid [25,42,43] and uvaol [44] produced vasodilation in rat aorta. In the present study, ursolic acid and uvaol relaxed the rat aorta by a mechanism that depends on the presence of the vascular endothelium. These results are consistent with an earlier survey, which demonstrated that ursolic acid causes an endothelium-dependent vasodilation [42]. In contrast, our findings regarding uvaol significantly disagree with a former investigation carried out by Rodríguez-Rodríguez et al. [44], who stated that uvaol elicited an endothelium-independent vasorelaxation, when tested in aortic rings from spontaneously hypertensive rats. In this regard, it has been described that some changes occur in vascular reactivity and morphology of thoracic aorta from normal and hypertensive rats [45-47]. The underlying etiology of these changes is multifactorial and strongly depends on the experimental model employed. Therefore, differences observed between our results and those reported by Rodríguez-Rodríguez et al. [44] might be attributed to either morphological or functional variations in the two experimental models.

The above-mentioned works by Aguirre-Crespo et al. [42] and Rodríguez-Rodríguez et al. [44] explored involvement of the NO/cGMP pathway in the vasodilatory effect of ursolic acid and uvaol, respectively. It was found that ursolic acid-induced vasorelaxation was blocked by L-NAME [42]. Contrastingly, relaxant response of uvaol was not modified by pretreatment with the same eNOS inhibitor [44]. In the present work, vasodilation by ursolic acid and uvaol was significantly reduced in the presence of L-NAME, which supports the hypothesis that these compounds activate the $\mathrm{NO} / \mathrm{cGMP}$ pathway. Additionally, we investigated whether vasodilation elicited by these triterpenes involved participation of the $\mathrm{H}_{2} \mathrm{~S} / \mathrm{K}_{\text {ATP }}$ channel pathway. We found that, in fact, the CSE inhibitor, DL-propargylglycine, inhibited dilatation of rat aorta produced by ursolic acid and uvaol. One of the primary mechanisms by which $\mathrm{H}_{2} \mathrm{~S}$, synthetized in endothelial cells, induces vasorelaxation is activation of $\mathrm{K}_{\mathrm{ATP}}$ channels located in vascular smooth muscle cells $[48,49]$. Therefore, participation of these latter channels in the vasodilation produced by both triterpenes was evaluated. Glibenclamide caused a significant reduction in the vasodilator effect of ursolic acid and uvaol, suggesting that $\mathrm{K}_{\text {ATP }}$ channels contribute to their effect. Taken together, these results provided additional evidence for the involvement of the $\mathrm{H}_{2} \mathrm{~S} / \mathrm{K}_{\text {ATP }}$ channel pathway in the triterpenes-induced vasorelaxation.

Moreover, simultaneous addition of submaximal concentrations of eNOS and CSE inhibitors almost completely blocked the vasorelaxant effect of either triterpenes. This potentiated response might be explained by a direct activation of both signaling pathways, which are closely interrelated and whose stimulation, according to numerous reports, triggers a complex cascade of interconnected chemical reactions that produce polysulfides and anionic $S / N$-hybrid species that are capable of producing vasodilation [50-52].

Further confirmation of our results was obtained when it was found that nitrite and $\mathrm{H}_{2} \mathrm{~S}$ levels were significantly increased in aortic tissues, which had been incubated in the presence of either ursolic acid or uvaol. This evidence strongly suggests that both triterpenes activate the NO/cGMP and $\mathrm{H}_{2} \mathrm{~S} / \mathrm{K}_{\text {ATP }}$ channel pathways, likely through a direct activation of the enzymes eNOS and CSE. 
An in silico analysis was performed to predict possible interactions between ursolic acid and uvaol and eNOS and CSE. The quaternary structure of eNOS consists of a homodimeric enzyme with several domains each monomer: a reductase-like domain, an oxidase-like catalytic site, a regulatory calmodulin binding loop, and four cysteines bound to $\mathrm{Zn}^{2+}$, which acts as a bridge between both monomers. Noteworthy, this enzyme needs five different cofactors to perform its function: FMN, FAD, NADPH, tetrahydrobiopterin and a heme group [53-55]. Thus, the great complexity of this protein has made difficult the crystallization of the whole enzyme, and up to now, there is no crystallographic structure featuring the aforementioned structural characteristics. Nevertheless, a number of crystallographic structures has been reported, which describe only the oxidase-like domain due to its importance for drug design and discovery of eNOS modulators [56].

In this work, a crystallographic structure of the oxidase-like domain was used with a molecule of tetrahydrobiopterin, a heme group and an eNOS inhibitor bound to the catalytic site. The catalytic site is located near the homodimeric interface, above the Zn-Cys cluster that stabilizes the homodimer and is conformed by several cavities: the substrate binding pocket above the heme group (S), two cavities that form the substrate entrance channel (C1 and C2), and a site that connects the aforementioned cavities (M) $[43,57,58]$. The binding sites of both triterpenes were located relatively far from the catalytic site, which indicated that the interaction of these compounds would not interfere with the binding of the substrate. We found that the docked triterpenes bind to specific amino acid residues that make up the $\mathrm{C} 1$ and $\mathrm{C} 2$ sites of eNOS, as described previously for ursolic acid and other triterpenes [43]. The docking scores of both triterpenes suggest that ursolic acid would have more affinity to the binding site than uvaol; thus, the effect on the quaternary structure of eNOS of the former would be greater than the effect of the latter. However, the difference of docking scores is less than $1 \mathrm{kcal} / \mathrm{mol}$, thus the binding of both triterpenes could be considered to have a similar affinity for the binding site.

On the other hand, CSE is a homotetramer with a catalytic site dependent of pyridoxal-phosphate (PLP) bound to a lysine, and 3 interfaces: one, which is formed at the center of the tetramer and is stabilized by PLP, one, which divides the tetramer by half, and one, which is near the catalytic sites of each monomer. As opposed to eNOS, few crystallographic structures of CSE have been reported with the covalent inhibitor DL-propargylglycine (PAG), which revealed important residues that are in the catalytic site and are important for the proper function of this site [59]. The interface near the catalytic sites forms a "trench" with enough space to bind ligands and possibly constitutes a substrate access channel to the active site. As in the case of eNOS, the binding sites of both triterpenes were relatively far from the catalytic site and were stabilized by hydrogen bonds. Ursolic acid showed better docking score than uvaol; thus, the affinity and effect on the quaternary structure of CSE of the former would be greater than the affinity and effect of the latter. Also, the difference of docking scores is small; thus, a similar affinity to the binding site could be expected. Considering the influence of a small cofactor like PLP in the stabilization of the quaternary structure of CSE, the binding of these triterpenes to the interface could have a great impact in the structure of the catalytic site.

The results derived from the in silico study support the hypothesis that ursolic acid and uvaol might directly activate eNOS and CSE. Here, we show for the first time that ursolic acid and uvaol are able to bind with high affinity to an allosteric binding site in both enzymes. Once the triterpenes bind to eNOS and CSE, the proposed binding site found in this work could act as an allosteric site or could stabilize the quaternary structure of the active site, resulting in the activation of these enzymes. Noteworthy, with these computational studies, a promissory new binding site that could act as an allosteric control site has been found for both enzymes. These calculations agree with the experimental observations, making possible to suggest a mode of action for the triterpenes. In forthcoming works, more calculations will be performed to corroborate these findings and to assess precisely the main interaction residues and the nature of those interactions.

The results obtained from the ex vivo, in vitro, and in silico studies carried out in the present research constitute a solid starting point for future investigations designed to further confirm direct 
activation of eNOS and CSE by these ursane type triterpenes in the search of prototypes for the development of novel antihypertensive drugs.

\section{Materials and Methods}

\subsection{Plant Material and Reagents}

The mature fruits of P. serotina were collected in orchards located in Huejotzingo, Puebla, México. The specimens were identified (P. serotina voucher 1414006) and deposited in the Herbario Nacional de México, Instituto de Biología, Universidad Nacional Autónoma de México.

The reagents and solvents used in the bio-directed chemical study were obtained from JT Baker (Phillipsburg, NJ, USA). The standards for the pharmacological and biochemical assays were purchased from Sigma-Aldrich (St. Louis, MO, USA).

\subsection{Experimental Animals}

Wistar male rats (250-300 g) were used for the pharmacological study; they were provided by the Institute of Neurobiology of the National Autonomous University of Mexico, Campus Juriquilla. All experiments were performed according to the indications of the Mexican Official Standard NOM-062-ZOO-1999 concerning the production, care and use of laboratory animals (Norma Oficial Mexicana, 2001).

\subsection{Collection and Preservation of Plant Material}

The harvested fruits were transported to the Laboratory of Natural Products of the Chemistry Faculty of the Autonomous University of Queretaro, in Queretaro, Mexico. Subsequently, the harvested fruits were selected based on their physical integrity, washed with water and dried completely. The fruits were segmented and, after the removal of seeds, frozen at $-70^{\circ} \mathrm{C}$, and lyophilized.

\subsection{Bio-Directed Chemical Study of the Dichloromethane Extract Obtained from the Fruits of P. serotina}

\subsubsection{Preparation of the Dichloromethane Extract from the Fruits of P. serotina}

To obtain the extract, the lyophilized fruits were subjected to maceration with dichloromethane for one week in a 1:3 ratio $(w / v)$. At the end of this time, the extract was filtered and the solvent was removed using a rotary evaporator. The resulting extract was stored at $-20{ }^{\circ} \mathrm{C}$.

4.4.2. Bio-Directed Fractionation of the Dichloromethane Extract and Purification of Ursolic Acid and Uvaol

The dichloromethane extract was subjected to an initial fractionation by column chromatography on normal phase using an open silica gel column (100 g, Kiesegel 60 Merck 70-230 mesh, particle size of $0.063-0.200 \mathrm{~mm}$ ). Hexane and acetone were used as eluents in various proportions to obtain the fractions, which were grouped according to their chromatographic similarity.

The resulting fractions were subjected to pharmacological evaluation using the isolated rat aorta assay to identify the bioactive fractions. The activity of each fraction was evaluated at a concentration equal to the mean effective concentration $\left(\mathrm{EC}_{50}\right)$ of the dichloromethane extract $(90 \mu \mathrm{g} / \mathrm{mL})$.

The purification of ursolic acid and uvaol from the active fraction PD-III was performed in the same manner as the initial fractionation: by open column chromatography on silica gel, using hexane and acetone in different proportions as eluents. The purity of ursolic acid and uvaol was verified by thin-layer chromatography and by determining their melting points.

\subsubsection{Determination of the Chemical Structure of Ursolic Acid and Uvaol}

The structural elucidation of ursolic acid and uvaol was carried out by the analysis of their proton nuclear magnetic resonance $\left({ }^{1} \mathrm{H}-\mathrm{NMR}\right)$ and carbon- $13\left({ }^{13} \mathrm{C}-\mathrm{NMR}\right)$ spectra. These compounds 
were identified by direct comparison with an authentic sample and by comparing their spectroscopic constants with those reported in the literature [60,61].

\subsection{Determination of the Vasodilator Effect and Elucidation of the Mechanism of Action of Ursolic Acid and Uvaol}

\subsubsection{Isolated Rat Aorta Assay}

Rats were sacrificed by decapitation. The descending thoracic aorta was removed and placed in cold Krebs-Henseleit solution (126.8 mM NaCl, $5.9 \mathrm{mM} \mathrm{KCl}, 2.5 \mathrm{mM} \mathrm{CaCl}_{2}, 1.2 \mathrm{mM} \mathrm{MgSO}_{4}, 1.2 \mathrm{mM}$ $\mathrm{KH}_{2} \mathrm{PO}_{4}, 30 \mathrm{mM} \mathrm{NaHCO} 3$ and $5 \mathrm{mM}$ D-glucose; $\mathrm{pH}$ 7.4). The aorta was cut into rings of 4 to $5 \mathrm{~mm}$, which were mounted in incubation chambers with $7 \mathrm{~mL}$ of Krebs-Henseleit solution at $37^{\circ} \mathrm{C}$ and constant bubbling with a mixture of $95 \% \mathrm{O}_{2}$ and $5 \% \mathrm{CO}_{2}$. The tissues were subjected to a basal tension of $1.5 \mathrm{~g}$ and were allowed to stabilize for $60 \mathrm{~min}$. Once the tissues reached equilibrium, the segments were pre-contracted with a $100 \mathrm{mM} \mathrm{KCl}$ solution for $15 \mathrm{~min}$ to stimulate arterial smooth muscle. Subsequently, $\mathrm{KCl}$ was removed, allowing the aorta to stabilize until it reached basal tension again. After stabilization of the tissue, the test compounds were evaluated in a concentration range of 1 to $1000 \mu \mathrm{g} / \mathrm{mL}$ on the aortic rings pre-contracted with phenylephrine $(1 \mu \mathrm{M})$. The endothelial integrity of the preparations was determined by adding acetylcholine $(1 \mu \mathrm{M})$ to the chamber bath. Only arteries with a vasodilator response more than $70 \%$ were considered endothelium-intact. The changes in tension caused by the tested concentrations were detected by Grass FT03 force transducers coupled to a Grass 7D Polygraph; they were expressed as percentages of relaxation based on the contraction generated by adding phenylephrine $[62,63]$.

\subsubsection{Participation of the Endothelium in the Vasodilator Response}

To determine whether the vasodilator response was dependent on the vascular endothelium, assays on aorta segments without endothelium were performed. In these experiments, the endothelium was mechanically removed by gently rubbing the internal aortic ring surface with a wood rod. The absence of endothelium was confirmed at the start of the experiment, showing that the addition of $1 \mu \mathrm{M}$ of acetylcholine (ACh) did not induce more than $5 \%$ relaxation.

4.5.3. Evaluation of the Participation of the NO/cGMP and the $\mathrm{H}_{2} \mathrm{~S} / \mathrm{K}_{\text {ATP }}$ Channel Pathways in the Vasodilator Response

Involvement of these biochemical pathways in the vasodilator effect of the test compounds was evaluated by incubating the tissue for $20 \mathrm{~min}$ in the presence of inhibitors of specific enzymes of each of these pathways: (1) NO/cGMP pathway: $100 \mu \mathrm{M}$ NG-nitro-L-arginine methyl ester (L-NAME, inhibitor of NO synthase, NOS); and (2) $\mathrm{H}_{2} \mathrm{~S} / \mathrm{K}_{\text {ATP }}$ channel pathway: $10 \mathrm{mM}$ DL-propargylglycine (PAG, inhibitor of cystathionine- $\gamma$-lyase, CSE). To determine the involvement of the activation of the $\mathrm{K}_{\mathrm{ATP}}$ channels in the vasodilator effect of the test compounds, aortic segments were incubated for $20 \mathrm{~min}$ in the presence of $1 \mu \mathrm{M}$ glibenclamide, a blocker of these channels, before adding the test compound [64,65].

Simultaneous inhibition of both enzymes, eNOS and CSE, was assessed employing submaximal concentrations of their respective inhibitors: $1 \mu \mathrm{M}$ L-NAME and $1 \mathrm{mM}$ PAG.

\subsection{Increase in $\mathrm{NO}$ and $\mathrm{H}_{2} \mathrm{~S}$ Levels Elicited by Ursolic Acid and Uvaol}

\subsubsection{NOS Enzymatic Activity Assay}

Aortic rings, previously incubated for $30 \mathrm{~min}$ with ursolic acid $\left(\mathrm{EC}_{50}=21.5 \pm 3.5 \mu \mathrm{g} / \mathrm{mL}\right.$ final concentration) or uvaol $\left(\mathrm{EC}_{50}=19.3 \pm 2.5 \mu \mathrm{g} / \mathrm{mL}\right.$ final concentration) or $\mathrm{ACh}\left(1 \times 10^{-4} \mathrm{M}\right.$ final concentration, positive control), were homogenized in phosphate buffer solution (PBS) $100 \mathrm{mM}$, $\mathrm{pH}$ 7.4. Homogenates were centrifuged at $24,400 \times \mathrm{g}$ for $20 \mathrm{~min}$ and the supernatant solutions were 
filtered. One hundred millimeter triplicate samples of filtered solutions were incubated for $3 \mathrm{~h}$ at room temperature in 96-well plates with PBS ( $\mathrm{pH} 7.4)$ containing nitrate reductase $(50 \mathrm{mU} / 100 \mu \mathrm{L}$ of sample) and NADPH ( $80 \mu \mathrm{M}$, final concentration). After the incubation time, $50 \mu \mathrm{L}$ of $1 \%$ sulfanilic acid and $50 \mu \mathrm{L}$ of $0.2 \% N$-naphthyl ethylenediamine were added to induce formation of a colored azo compound. Absorbance was measured at $540 \mathrm{~nm}$ and samples concentrations were calculated with a linear equation based on a $\mathrm{NO}_{2}{ }^{-}$calibration curve [66,67].

\subsubsection{CSE Enzymatic Activity Assay}

Aortic segments were homogenized in PBS pH 7.4 with a protease inhibitor (Sigmafast protease inhibitor cocktail tablets, EDTA free) and centrifuged at $16,945 \times g$ for $15 \mathrm{~min}$ at $4{ }^{\circ} \mathrm{C}$. The supernatant $(350 \mu \mathrm{L})$ was added with: $50 \mu \mathrm{L}$ of the triterpenes at the $\mathrm{EC}_{50}$ obtained from the concentration-response curves of ursolic acid $(21.5 \pm 3.5 \mu \mathrm{g} / \mathrm{mL}$ final concentration $)$ and uvaol $(19.3 \pm 2.5 \mu \mathrm{g} / \mathrm{mL}$ final concentration) or $\mathrm{ACh}\left(1 \times 10^{-4} \mathrm{M}\right.$ final concentration), $25 \mu \mathrm{L}$ of $2 \mathrm{mM}$ pyridoxal $5^{\prime}$ phosphate, and $25 \mu \mathrm{L}$ of $10 \mathrm{mM}$ L-cysteine. This mixture was left to react for $60 \mathrm{~min}$ in a $37^{\circ} \mathrm{C}$ shaking water bath and the reaction was ended by adding $250 \mu \mathrm{L}$ of $1 \%$ zinc acetate to trap $\mathrm{H}_{2} \mathrm{~S}$. Afterwards, $250 \mu \mathrm{L}$ of $10 \%$ trichloroacetic acid and $200 \mu \mathrm{L}$ of $20 \mathrm{mM} \mathrm{N}, N$-diethyl-p-phenylenediamine sulphate in $1.2 \mathrm{M} \mathrm{HCl}$ were added, followed by addition of $200 \mu \mathrm{L}$ of $30 \mathrm{mM}$ iron trichloride in $1.2 \mathrm{M} \mathrm{HCl}$. After $20 \mathrm{~min}$, absorbance was measured at $670 \mathrm{~nm}$ and $\mathrm{H}_{2} \mathrm{~S}$ concentration was calculated against a calibration curve of standard NaHS solution (5 to $100 \mu \mathrm{M})$ [68,69].

\subsection{In silico Studies}

In silico studies were conducted by using Schrödinger Maestro Suite 2014-1 (Schrödinger, LLC, New York, NY, USA, 2014). File preparation and docking studies were performed on this software.

\subsubsection{Protein Preparation}

The crystallographic structures of eNOS (PDB: 1D0C) and CSE (PDB: 3COG) were suitably obtained and prepared using Protein Preparation Wizard [70] available in Maestro (Protein Preparation Wizard; Epik version 2.7, Schrödinger, LLC, 2013; Impact version 6.2, Schrödinger, LLC, 2014; Prime version 3.5, Schrödinger, LLC, 2014). Briefly, all missing residues were added, all ligands except cofactors and crystallographic waters were removed. Finally, the structures were protonated to physiological $\mathrm{pH}(7.0 \pm 0.5)$ and the protonated structures were minimized using Optimized Potentials for Liquid Simulations (OPLS) force field.

\subsubsection{Ligand Preparation}

The structures of ursolic acid and uvaol were obtained from PubChem [71] (entries 64945 and 92802, respectively) and prepared with LigPrep on Maestro (LigPrep, version 2.9, Schrödinger, LLC, 2014), selecting the minimized structure for docking studies.

\subsubsection{Docking Studies}

These studies were conducted by using Glide 6.2 [72-74] with default parameters, available in Maestro (Glide, version 6.2, Schrödinger, LLC, 2014). First, a blind docking protocol was used to assess the highest affinity site for the compounds; once the binding site was located, docking calculations were performed using Glide 6.2 Extra Precision (XP) in the neighborhood of the binding site using the default parameters. As a validation of the protocol used, redocking of crystallographic ligands were made on eNOS.

\subsection{Statistical Analysis}

Six evaluations were performed for each of the concentrations of the test substances. The results are expressed as the mean \pm standard error of the mean (SEM). The experimental data generated 
during each evaluation were fitted to a sigmoidal equation and plotted using the software PRISM 5.0 GraphPad (Graph Pad Software Inc., San Diego, CA, USA) to obtain concentration-response curves. The $\mathrm{EC}_{50}$ was calculated for each case.

Concentration-response curves were analyzed by repeated-measures two-way ANOVA, using the statistical program PRISM 5.0 GraphPad, followed by the Bonferroni test to evaluate any significant differences between the means. In Figure 3, comparison was made between the curves of each triterpene in the presence and absence of endothelium. In Figures 4-6 concentration-response curves of ursolic acid and uvaol were compared with the respective concentration-response curves obtained in the presence of the different inhibitors tested. The concentration-response curves of ursolic acid and uvaol were only constructed once (Figure 3), and they were used as controls in Figures 4-6.

Comparisons between two populations in the NOS and CSE enzymatic activity assays were made using a one-way ANOVA, followed by a Tukey's test.

\section{Conclusions}

In this paper, we report for the first time that the main non-polar vasodilatory compounds in $P$. serotina fruits are ursolic acid and uvaol. In addition, this study is the first that proposes involvement of the $\mathrm{H}_{2} \mathrm{~S} / \mathrm{K}_{\text {ATP }}$ channel pathway in the vasodilator effect induced by these triterpenes. Participation of the NO/cGMP pathway in the vasodilation produced by these compounds was also confirmed. Moreover, we demonstrated that ursolic acid and uvaol are able to activate simultaneously both $\mathrm{NO} / \mathrm{cGMP}$ and the $\mathrm{H}_{2} \mathrm{~S} / \mathrm{K}_{\text {ATP }}$ channel pathways, which results in a synergistic vasorelaxant effect. In silico studies indicated, that these compounds might activate both eNOS and CSE by binding to an allosteric control site located in the enzymes. Therefore, both secondary metabolites can be considered as prototype molecules with a novel mechanism of action for the development of drugs useful in the prevention and/or treatment of cardiovascular diseases, such as hypertension.

Acknowledgments: This work was supported by grant FOFI-UAQ 2014 (FCQ-2014-20) from the Autonomous University of Queretaro. Francisco J. Luna-Vázquez acknowledges Consejo Nacional de Ciencia y Tecnología (CONACYT) for his Postdoctoral grant.

Author Contributions: Francisco J. Luna-Vázquez carried out the phytochemical study of Prunus serotina fruits, conducted the pharmacological and biochemical assays directed towards the characterization of the mechanism of action of uvaol and ursolic acid, and revised the manuscript. César Ibarra-Alvarado designed this project, coordinated all the activities, and contributed with the preparation of the manuscript. Alejandra Rojas-Molina supervised the phytochemical study of P. serotina fruits and contributed with the preparation of the manuscript. Antonio Romo-Mancillas performed the in silico analysis to assess possible interactions between the triterpenes and CSE, and contributed with the preparation of the manuscript Fabián Harvey López Vallejo carried out the in silico analysis to explore possible interactions between the triterpenes and eNOS. Mariana Solís-Gutiérrez helped in carrying out the biochemical assays. J. Isela Rojas-Molina suggested improvements in the manuscript. Fausto Rivero-Cruz conducted the final identification of ursolic acid and uvaol.

Conflicts of Interest: The authors declare no conflict of interest.

\section{References}

1. Go, A.S.; Mozaffarian, D.; Roger, V.L.; Benjamin, E.J.; Berry, J.D.; Borden, W.B.; Bravata, D.M.; Dai, S.; Ford, E.S.; Fox, C.S.; et al. Heart disease and stroke statistics-2013 update: A report from the American Heart Association. Circulation 2013, 127, e6-e245. [CrossRef] [PubMed]

2. WHO. World Health Organization. The Top 10 Causes of Death. Available online: http://www.who.int/ mediacentre/factsheets/fs310/en/ (accessed on 10 January 2014).

3. Leon, B.M.; Maddox, T.M. Diabetes and cardiovascular disease: Epidemiology, biological mechanisms, treatment recommendations and future research. World J. Diabetes 2015, 6, 1246-1258. [CrossRef] [PubMed]

4. Velázquez Monroy, Ó.; Barinagarrementería Aldatz, F.S.; Rubio Guerra, A.F.; Verdejo, J.; Méndez Bello, M.Á.; Violante, R.; Pavía, A.; Alvarado-Ruiz, R.; Lara Esqueda, A. Morbilidad y mortalidad de la enfermedad isquémica del corazón y cerebrovascular en México. 2005. Arch. Cardiol. Méx. 2007, 77, 31-39.

5. INEGI. Causas de Defunción en México 2013. Available online: http:/ /www3.inegi.org.mx/sistemas/sisept/ Default.aspx?t=mdemo107\&s=est\&c=23587 (accessed on 12 February 2014). 
6. Borja-Aburto, V.H.; Gonzalez-Anaya, J.A.; Davila-Torres, J.; Rascon-Pacheco, R.A.; Gonzalez-Leon, M. Evaluation of the impact on non-communicable chronic diseases of a major integrated primary health care program in Mexico. Fam. Pract. 2015. [CrossRef]

7. Wu, F.; Guo, Y.; Chatterji, S.; Zheng, Y.; Naidoo, N.; Jiang, Y.; Biritwum, R.; Yawson, A.; Minicuci, N.; Salinas-Rodriguez, A.; et al. Common risk factors for chronic non-communicable diseases among older adults in China, Ghana, Mexico, India, Russia and South Africa: The study on global ageing and adult health (sage) wave 1. BMC Public Health 2015, 15. [CrossRef] [PubMed]

8. Bakris, G.; Sarafidis, P.; Agarwal, R.; Ruilope, L. Review of blood pressure control rates and outcomes. J. Am. Soc. Hypertens. 2014, 8, 127-141. [CrossRef] [PubMed]

9. Triggle, C.R.; Samuel, S.M.; Ravishankar, S.; Marei, I.; Arunachalam, G.; Ding, H. The endothelium: Influencing vascular smooth muscle in many ways. Can. J. Physiol. Pharmacol. 2012, 90, 713-738. [CrossRef] [PubMed]

10. Kang, K.T. Endothelium-derived relaxing factors of small resistance arteries in hypertension. Toxicol. Res. 2014, 30, 141-148. [CrossRef] [PubMed]

11. Wang, R.; Szabo, C.; Ichinose, F.; Ahmed, A.; Whiteman, M.; Papapetropoulos, A. The role of $\mathrm{H}_{2} \mathrm{~S}$ bioavailability in endothelial dysfunction. Trends Pharmacol. Sci. 2015, 36, 568-578. [CrossRef] [PubMed]

12. Laurent, S.; Schlaich, M.; Esler, M. New drugs, procedures, and devices for hypertension. Lancet 2012, 380, 591-600. [CrossRef]

13. Galie, N.; Ghofrani, A.H. New horizons in pulmonary arterial hypertension therapies. Eur. Respir. Rev. 2013, 22, 503-514. [CrossRef] [PubMed]

14. Wang, R. Hydrogen sulfide: The third gasotransmitter in biology and medicine. Antioxid. Redox Signal. 2010, 12, 1061-1064. [CrossRef] [PubMed]

15. Bryan, N.S. Application of nitric oxide in drug discovery and development. Expert Opin. Drug Discov. 2011, 6, 1139-1154. [CrossRef] [PubMed]

16. Kots, A.Y.; Bian, K.; Murad, F. Nitric oxide and cyclic GMP signaling pathway as a focus for drug development. Curr. Med. Chem. 2011, 18, 3299-3305. [CrossRef] [PubMed]

17. Evora, P.R.; Evora, P.M.; Celotto, A.C.; Rodrigues, A.J.; Joviliano, E.E. Cardiovascular therapeutics targets on the NO-sGC-cGMP signaling pathway: A critical overview. Curr. Drug Targets 2012, 13, 1207-1214. [CrossRef] [PubMed]

18. Holwerda, K.M.; Faas, M.M.; van Goor, H.; Lely, A.T. Gasotransmitters a solution for the therapeutic dilemma in preeclampsia? Hypertension 2013, 62, 653-659. [CrossRef] [PubMed]

19. Russwurm, M.; Russwurm, C.; Koesling, D.; Mergia, E. NO/cGMP: The past, the present, and the future. In Guanylate Cyclase and Cyclic GMP: Methods and Protocols; Springer Science + Business Media, LLC: New York, NY, USA, 2013; pp. 1-16.

20. Bełtowski, J. Hydrogen sulfide in pharmacology and medicine-An update. Pharmacol. Rep. 2015, 67, 647-658. [CrossRef] [PubMed]

21. Dasgupta, A.; Bowman, L.; D'Arsigny, C.L.; Archer, S.L. Soluble guanylate cyclase: A new therapeutic target for pulmonary arterial hypertension and chronic thromboembolic pulmonary hypertension. Clin. Pharmacol. Ther. 2015, 97, 88-102. [CrossRef] [PubMed]

22. Holwerda, K.M.; Karumanchi, S.A.; Lely, A.T. Hydrogen sulfide: Role in vascular physiology and pathology. Curr. Opin. Nephrol. Hypertens. 2015, 24, 170-176. [CrossRef] [PubMed]

23. Zhao, Y.; Pacheco, A.; Xian, M. Medicinal chemistry: Insights into the development of novel $\mathrm{H}_{2} \mathrm{~S}$ donors. In Chemistry, Biochemistry and Pharmacology of Hydrogen Sulfide; Springer International Publishing: Cham, Switzerland, 2015; pp. 365-388.

24. Ibarra-Alvarado, C.; Rojas, A.; Mendoza, S.; Bah, M.; Gutiérrez, D.; Hernández-Sandoval, L.; Martínez, M. Vasoactive and antioxidant activities of plants used in Mexican traditional medicine for the treatment of cardiovascular diseases. Pharm. Biol. 2010, 48, 732-739. [CrossRef] [PubMed]

25. Ibarra-Alvarado, C.; Rojas, A.; Luna, F.; Rojas, J.I.; Rivero-Cruz, B.; Rivero-Cruz, J.F. Vasorelaxant constituents of the leaves of Prunus serotina "capulín". Rev. Latinoam. Quím. 2009, 37, 164-173.

26. De la Villa Torre, F.L.-V.F.; Ibarra-Alvarado, C.; Rivero-Cruz, F.; Rojas-Molina, J.I.; Rojas-Molina, A. Innovations in Food Science and Food Biotechnology in Developing Countries; Regalado, C.G., García, B.E., Eds.; Asociación Mexicana de Ciencias de los Alimentos: Mexico, D.F., Mexico, 2010; pp. 13-25. 
27. Luna-Vázquez, F.J.; Ibarra-Alvarado, C.; Rojas-Molina, A.; Rojas-Molina, J.I.; Yahia, E.M.; Rivera-Pastrana, D.M.; Rojas-Molina, A.; Zavala-Sánchez, Á.M. Nutraceutical value of black cherry Prunus serotina ehrh. Fruits: Antioxidant and antihypertensive properties. Molecules 2013, 18, 14597-14612. [CrossRef]

28. Jäger, S.; Trojan, H.; Kopp, T.; Laszczyk, M.N.; Scheffler, A. Pentacyclic triterpene distribution in various plants-rich sources for a new group of multi-potent plant extracts. Molecules 2009, 14, 2016-2031. [CrossRef] [PubMed]

29. Guinda, A.N.; Rada, M.; Delgado, T.; Gutiérrez-Adánez, P.; Castellano, J.M. Pentacyclic triterpenoids from olive fruit and leaf. J. Agric. Food Chem. 2010, 58, 9685-9691. [CrossRef] [PubMed]

30. Wolbis, M.; Olszewska, M.; Wesolowski, W.J. Triterpenes and sterols in the flowers and leaves of Prunus spinosa L. (rosaceae). Acta Poloniae Pharm. 2001, 58, 459-462. [PubMed]

31. Amico, V.; Barresi, V.; Condorelli, D.; Spatafora, C.; Tringali, C. Antiproliferative terpenoids from almond hulls (Prunus dulcis): Identification and structure-activity relationships. J. Agric. Food Chem. 2006, 54, 810-814. [CrossRef] [PubMed]

32. Marcia, M.; Konorov, S.O.; Schulze, H.G.; Blades, M.W.; Turner, R.F.; Jetter, R. In situ analysis by microspectroscopy reveals triterpenoid compositional patterns within leaf cuticles of Prunus laurocerasus. Planta 2008, 227, 823-834.

33. Kadu, C.A.; Parich, A.; Schueler, S.; Konrad, H.; Muluvi, G.M.; Eyog-Matig, O.; Muchugi, A.; Williams, V.L.; Ramamonjisoa, L.; Kapinga, C. Bioactive constituents in Prunus africana: Geographical variation throughout Africa and associations with environmental and genetic parameters. Phytochemistry 2012, 83, 70-78. [CrossRef] [PubMed]

34. Yan, X.-T.; Lee, S.-H.; Li, W.; Jang, H.-D.; Kim, Y.-H. Terpenes and sterols from the fruits of Prunus mume and their inhibitory effects on osteoclast differentiation by suppressing tartrate-resistant acid phosphatase activity. Arch. Pharm. Res. 2015, 38, 186-192. [CrossRef] [PubMed]

35. Chen, H.; Gao, Y.; Wang, A.; Zhou, X.; Zheng, Y.; Zhou, J. Evolution in medicinal chemistry of ursolic acid derivatives as anticancer agents. Eur. J. Med. Chem. 2015, 92, 648-655. [CrossRef] [PubMed]

36. Sultana, N. Clinically useful anticancer, antitumor, and antiwrinkle agent, ursolic acid and related derivatives as medicinally important natural product. J. Enzyme Inhib. Med. Chem. 2011, 26, 616-642. [CrossRef] [PubMed]

37. Camer, D.; Yu, Y.; Szabo, A.; Huang, X.F. The molecular mechanisms underpinning the therapeutic properties of oleanolic acid, its isomer and derivatives for type 2 diabetes and associated complications. Mol. Nutr. Food Res. 2014, 58, 1750-1759. [CrossRef] [PubMed]

38. Kang, S.Y.; Yoon, S.Y.; Roh, D.H.; Jeon, M.J.; Seo, H.S.; Uh, D.K.; Kwon, Y.B.; Kim, H.W.; Han, H.J.; Lee, H.J. The anti-arthritic effect of ursolic acid on zymosan-induced acute inflammation and adjuvant-induced chronic arthritis models. J. Pharm. Pharmacol. 2008, 60, 1347-1354. [CrossRef] [PubMed]

39. Li, H.; Forstermann, U. Prevention of atherosclerosis by interference with the vascular nitric oxide system. Curr. Pharm. Des. 2009, 15, 3133-3145. [CrossRef] [PubMed]

40. Allouche, Y.; Beltrán, G.; Gaforio, J.J.; Uceda, M.; Mesa, M.D. Antioxidant and antiatherogenic activities of pentacyclic triterpenic diols and acids. Food Chem. Toxicol. 2010, 48, 2885-2890. [CrossRef] [PubMed]

41. Sánchez-Quesada, C.; López-Biedma, A.; Gaforio, J.J. The differential localization of a methyl group confers a different anti-breast cancer activity to two triterpenes present in olives. Food Funct. 2015, 6, 248-255. [CrossRef] [PubMed]

42. Aguirre-Crespo, F.; Vergara-Galicia, J.; Villalobos-Molina, R.; López-Guerrero, J.J.; Navarrete-Vázquez, G.; Estrada-Soto, S. Ursolic acid mediates the vasorelaxant activity of Lepechinia caulescens via NO release in isolated rat thoracic aorta. Life Sci. 2006, 79, 1062-1068. [CrossRef] [PubMed]

43. Rios, M.Y.; López-Martínez, S.; López-Vallejo, F.; Medina-Franco, J.L.; Villalobos-Molina, R.; Ibarra-Barajas, M.; Navarrete-Vazquez, G.; Hidalgo-Figueroa, S.; Hernández-Abreu, O.; Estrada-Soto, S. Vasorelaxant activity of some structurally related triterpenic acids from Phoradendron reichenbachianum (Viscaceae) mainly by NO production: Ex vivo and in silico studies. Fitoterapia 2012, 83, 1023-1029. [CrossRef] [PubMed]

44. Rodriguez-Rodriguez, R.; Perona, J.S.; Herrera, M.D.; Ruiz-Gutierrez, V. Triterpenic compounds from "orujo" olive oil elicit vasorelaxation in aorta from spontaneously hypertensive rats. J. Agric. Food Chem. 2006, 54, 2096-2102. [CrossRef] [PubMed] 
45. Török, J.; Kristek, F. Functional and morphological pattern of vascular responses in two models of experimental hypertension. Exp. Clin. Cardiol. 2001, 6, 142-148. [PubMed]

46. Torok, J.; Koprdová, R.; Cebová, M.; Kunes, J.; Kristek, F. Functional and structural pattern of arterial responses in hereditary hypertriglyceridemic and spontaneously hypertensive rats. Physiol. Res. 2006, 55, S65-S71. [PubMed]

47. Ajay, M.; Achike, F.I.; Mustafa, M.R. Modulation of vascular reactivity in normal, hypertensive and diabetic rat aortae by a non-antioxidant flavonoid. Pharmacol. Res. 2007, 55, 385-391. [CrossRef] [PubMed]

48. Bełtowski, J.; Jamroz-Wiśniewska, A. Hydrogen sulfide and endothelium-dependent vasorelaxation. Molecules 2014, 19, 21183-21199. [CrossRef] [PubMed]

49. Mustafa, A.K.; Sikka, G.; Gazi, S.K.; Steppan, J.; Jung, S.M.; Bhunia, A.K.; Barodka, V.M.; Gazi, F.K.; Barrow, R.K.; Wang, R. Hydrogen sulfide as endothelium-derived hyperpolarizing factor sulfhydrates potassium channels. Circ. Res. 2011, 109, 1259-1268. [CrossRef] [PubMed]

50. Kajimura, M.; Fukuda, R.; Bateman, R.M.; Yamamoto, T.; Suematsu, M. Interactions of multiple gas-transducing systems: Hallmarks and uncertainties of $\mathrm{CO}, \mathrm{NO}$, and $\mathrm{H}_{2} \mathrm{~S}$ gas biology. Antioxid. Redox Signal. 2010, 13, 157-192. [CrossRef] [PubMed]

51. Berenyiova, A.; Grman, M.; Mijuskovic, A.; Stasko, A.; Misak, A.; Nagy, P.; Ondriasova, E.; Cacanyiova, S.; Brezova, V.; Feelisch, M. The reaction products of sulfide and s-nitrosoglutathione are potent vasorelaxants. Nitric Oxide 2015, 46, 123-130. [CrossRef] [PubMed]

52. Cortese-Krott, M.M.; Fernandez, B.O.; Kelm, M.; Butler, A.R.; Feelisch, M. On the chemical biology of the nitrite/sulfide interaction. Nitric Oxide 2015, 46, 14-24. [CrossRef] [PubMed]

53. Stuehr, D.; Pou, S.; Rosen, G.M. Oxygen reduction by nitric-oxide synthases. J. Biol. Chem. 2001, 276, 14533-14536. [CrossRef] [PubMed]

54. Fischmann, T.O.; Hruza, A.; da Niu, X.; Fossetta, J.D.; Lunn, C.A.; Dolphin, E.; Prongay, A.J.; Reichert, P.; Lundell, D.J.; Narula, S.K. Structural characterization of nitric oxide synthase isoforms reveals striking active-site conservation. Nat. Struct. Mol. Biol. 1999, 6, 233-242. [CrossRef] [PubMed]

55. Raman, C.; Li, H.; Martásek, P.; Southan, G.; Masters, B.S.S.; Poulos, T.L. Crystal structure of nitric oxide synthase bound to nitro indazole reveals a novel inactivation mechanism. Biochemistry 2001, 40, 13448-13455. [CrossRef]

56. Alderton, W.; Cooper, C.; Knowles, R. Nitric oxide synthases: Structure, function and inhibition. Biochem. J. 2001, 357, 593-615. [CrossRef] [PubMed]

57. Ji, H.; Li, H.; Flinspach, M.; Poulos, T.L.; Silverman, R.B. Computer modeling of selective regions in the active site of nitric oxide synthases: Implication for the design of isoform-selective inhibitors. J. Med. Chem. 2003, 46, 5700-5711. [CrossRef] [PubMed]

58. Stuehr, D.J.; Santolini, J.; Wang, Z.-Q.; Wei, C.-C.; Adak, S. Update on mechanism and catalytic regulation in the NO synthases. J. Biol. Chem. 2004, 279, 36167-36170. [CrossRef] [PubMed]

59. Sun, Q.; Collins, R.; Huang, S.; Holmberg-Schiavone, L.; Anand, G.S.; Tan, C.-H.; van-den-Berg, S.; Deng, L.-W.; Moore, P.K.; Karlberg, T. Structural basis for the inhibition mechanism of human cystathionine $\gamma$-lyase, an enzyme responsible for the production of $\mathrm{H}_{2}$ S. J. Biol. Chem. 2009, 284, 3076-3085. [CrossRef] [PubMed]

60. Mallavadhani, U.; Panda, A.K.; Rao, Y. Diospyros melanoxylon leaves: A rich source of pentacyclic triterpenes. Pharm. Biol. 2001, 39, 20-24. [CrossRef]

61. Sang, S.; Lapsley, K.; Rosen, R.T.; Ho, C.-T. New prenylated benzoic acid and other constituents from almond hulls (Prunus amygdalus Batsch). J. Agric. Food Chem. 2002, 50, 607-609. [CrossRef] [PubMed]

62. Feelisch, M.; Kotsonis, P.; Siebe, J.; Clement, B.; Schmidt, H.H. The soluble guanylyl cyclase inhibitor $1 H$-[1,2,4] oxadiazolo [4,3,-a] quinoxalin-1-one is a nonselective heme protein inhibitor of nitric oxide synthase and other cytochrome p-450 enzymes involved in nitric oxide donor bioactivation. Mol. Pharmacol. 1999, 56, 243-253. [PubMed]

63. Ibarra-Alvarado, C.; García, J.A.; Aguilar, M.B.; Rojas, A.; Falcón, A.; de la Cotera, E.P.H. Biochemical and pharmacological characterization of toxins obtained from the fire coral Millepora complanata. Comp. Biochem. Physiol. Part C Toxicol. Pharmacol. 2007, 146, 511-518. [CrossRef] [PubMed]

64. Galle, J.; Zabel, U.; Hübner, U.; Hatzelmann, A.; Wagner, B.; Wanner, C.; Schmidt, H.H. Effects of the soluble guanylyl cyclase activator, YC-1, on vascular tone, cyclic GMP levels and phosphodiesterase activity. Br. J. Pharmacol. 1999, 127, 195-203. [CrossRef] [PubMed] 
65. Ibarra-Alvarado, C.; Galle, J.; Melichar, V.O.; Mameghani, A.; Schmidt, H.H. Phosphorylation of blood vessel vasodilator-stimulated phosphoprotein at serine 239 as a functional biochemical marker of endothelial nitric oxide/cyclic GMP signaling. Mol. Pharmacol. 2002, 61, 312-319. [CrossRef] [PubMed]

66. Chang, M.-L.; Chang, J.-S.; Yu, W.-Y.; Cheah, K.-P.; Li, J.-S.; Cheng, H.-W.; Hu, C.-M. Polygonum viviparum L. Induces vasorelaxation in the rat thoracic aorta via activation of nitric oxide synthase in endothelial cells. BMC Complement. Altern. Med. 2014, 14. [CrossRef] [PubMed]

67. Guevara, I.; Iwanejko, J.; Dembińska-Kieć, A.; Pankiewicz, J.; Wanat, A.; Anna, P.; Gołąbek, I.; Bartuś, S.; Malczewska-Malec, M.; Szczudlik, A. Determination of nitrite/nitrate in human biological material by the simple Griess reaction. Clin. Chim. Acta 1998, 274, 177-188. [CrossRef]

68. Cheung, S.H.; Kwok, W.K.; To, K.F.; Lau, J.Y.W. Anti-atherogenic effect of hydrogen sulfide by over-expression of cystathionine gamma-lyase (CSE) gene. PLoS ONE 2014, 9, e113038. [CrossRef] [PubMed]

69. Bucci, M.; Papapetropoulos, A.; Vellecco, V.; Zhou, Z.; Pyriochou, A.; Roussos, C.; Roviezzo, F.; Brancaleone, V.; Cirino, G. Hydrogen sulfide is an endogenous inhibitor of phosphodiesterase activity. Arterioscler. Thromb. Vasc. Biol. 2010, 30, 1998-2004. [CrossRef] [PubMed]

70. Sastry, G.M.; Adzhigirey, M.; Day, T.; Annabhimoju, R.; Sherman, W. Protein and ligand preparation: Parameters, protocols, and influence on virtual screening enrichments. J. Comput. Aided Mol. Des. 2013, 27, 221-234. [CrossRef] [PubMed]

71. Bolton, E.E.; Wang, Y.; Thiessen, P.A.; Bryant, S.H. Pubchem: Integrated platform of small molecules and biological activities. Annu. Rep. Comput. Chem. 2008, 4, 217-241.

72. Friesner, R.A.; Banks, J.L.; Murphy, R.B.; Halgren, T.A.; Klicic, J.J.; Mainz, D.T.; Repasky, M.P.; Knoll, E.H.; Shelley, M.; Perry, J.K. Glide: A new approach for rapid, accurate docking and scoring. 1. Method and assessment of docking accuracy. J. Med. Chem. 2004, 47, 1739-1749. [CrossRef] [PubMed]

73. Halgren, T.A.; Murphy, R.B.; Friesner, R.A.; Beard, H.S.; Frye, L.L.; Pollard, W.T.; Banks, J.L. Glide: A new approach for rapid, accurate docking and scoring. 2. Enrichment factors in database screening. J. Med. Chem. 2004, 47, 1750-1759. [CrossRef] [PubMed]

74. Friesner, R.A.; Murphy, R.B.; Repasky, M.P.; Frye, L.L.; Greenwood, J.R.; Halgren, T.A.; Sanschagrin, P.C.; Mainz, D.T. Extra precision glide: Docking and scoring incorporating a model of hydrophobic enclosure for protein-ligand complexes. J. Med. Chem. 2006, 49, 6177-6196. [CrossRef] [PubMed]

Sample Availability: Samples of ursolic acid and uvaol are not available from the authors.

(C) 2016 by the authors; licensee MDPI, Basel, Switzerland. This article is an open access article distributed under the terms and conditions of the Creative Commons by Attribution (CC-BY) license (http:/ / creativecommons.org/licenses/by/4.0/). 